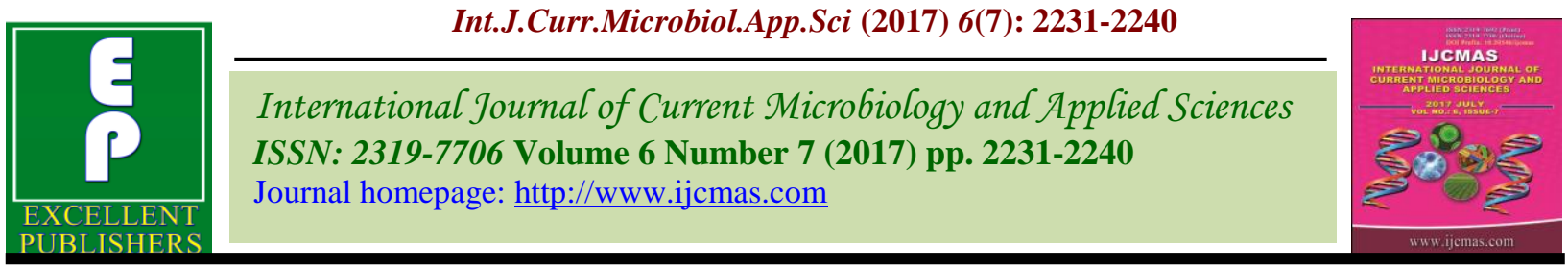

Original Research Article

https://doi.org/10.20546/ijcmas.2017.607.262

\title{
Generation Mean Analysis for Yield and Yield Components in Cowpea [Vigna unguiculata (L.) Walp.]
}

\author{
R.P. Gupta*, S.R. Patel, K.G. Modha and P.B. Wadekar \\ Navsari Agricultural University, Navsari-396450 (Gujarat), India \\ *Corresponding author
}

\section{A B S T R A C T}

\begin{tabular}{l} 
K e y w o r d s \\
$\begin{array}{l}\text { Cowpea, Gene } \\
\text { action, Generation } \\
\text { mean analysis, } \\
\text { Seed yield and } \\
\text { yield components. }\end{array}$ \\
\hline Article Info \\
$\begin{array}{l}\text { Accepted: } \\
\text { 21 June } 2017 \\
\text { Available Online: } \\
\text { 10 July } 2017\end{array}$
\end{tabular}

Keywords

Cowpea, Gene action, Generation mean analysis, yield components.

\section{Introduction}

Pulses are economically cheaper and vital source of protein in Indian diet. India has a distinction of growing over a dozen of pulses and first in acreage, production and consumption. Despite per capita availability of pulses is dismally as low as $28 \mathrm{~g} / \mathrm{capita} / \mathrm{day}$ as against the optimum and minimum stipulation of 104 and $60 \mathrm{~g} /$ capita/day, respectively, as per WHO standards. The situation is dicey and often lead to malnutrition. The predicament still assumes volume, as the predominant Indians are vegetarians. Therefore, pulses may simply be termed as health line of the country and needs all out concerted efforts for enhancing their production. Cowpea [Vigna unguiculata (L.) Walp.], is an important multi utility crop locally known as lobiya, chowla (chowli), Southern pea or black eye pea, that is adopted to warm condition and cultivated in the tropics and sub-tropics for dry grains, green edible pods for vegetable as well as fodder. Cowpea fits well in a variety of cropping system and is grown as cover crop, mixed crop, catch crop and green manure crop. It can be capable of restoring soil fertility and therefore, remain an integral part of subsistence and sustainable production system. Being a legume crop, cowpea fix substantial quantities of biological nitrogen by virtue of their symbiotic association with Rhizobium bacteria (Schultze and Kondorosi, 1998) ranging from potential rates of $73-80$ $\mathrm{kg} /$ ha (Yamada, 1974). Cowpea is chiefly 
important as a source of protein and varies from $20-25 \%$ that is double of the protein in most cereals (Stanton, 1966). Presently, cowpea is an important pulse crop in India covering on an area of 7.7 million hectares (Yadav et al., 2010). However, the exact productivity statistics are not available though the broad estimates put it around five to six quintals per hectare.

The experimental yields of the improved genotypes have been reported around 15 quintals per hectare. In India, cowpea is grown in almost all the states but the major cowpea growing states are Gujarat, West Bengal, Tamil Nadu, Andhra Pradesh, Kerala and Orissa.

In a self-pollinating crop like cowpea, variability is often created through hybridization between carefully chosen parents. The scope of exploitation of hybrid vigour will depend on the direction and magnitude of heterosis, biological feasibilities and the type of gene action involved. The information of such estimates is essential to plan efficient breeding programme for the improvement of the crop. One of the common approaches followed to understand the nature of gene effects by growing different generations and carrying out the generation mean analysis, using first-degree statistics was employed in the present study.

\section{Materials and Methods}

The present study was carried out during kharif 2016-2017, at College Farm, N. M. College of Agriculture, Navsari Agricultural University, Navsari. The $F_{1}$ hybrids were generated by crossing of above eight parents during Rabi 2014-15. Backcrossing was done in summer 2015-16 and Kharif 2015-16 with its respective parents. Selfing of $\mathrm{F}_{1} \mathrm{~s}$ was done in the same season (summer and kharif 201516) to get $\mathrm{F}_{2} \mathrm{~S}$. The evaluation trial was conducted in Kharif 2016-17 at College Farm, N. M. College of Agriculture, Navsari Agricultural University, Navsari. The experimental material consisting of six generations $\left(\mathrm{P}_{1}, \mathrm{P}_{2}, \mathrm{~F}_{1}, \mathrm{~F}_{2}, \mathrm{BC}_{1}\right.$ and $\left.\mathrm{BC}_{2}\right)$ of each of the five crosses were sown during kharif-2016 in Compact Family Block Design with three replications.

Each replication was divided in five compact blocks. Each five crosses consisting of six generations were randomly allotted to the blocks. Six generations were than randomly allotted to each plot within a block.

Each plot consisted of one row of parents and $\mathrm{F}_{1} \mathrm{~s}$, two rows of the backcrosses and four rows of the $\mathrm{F}_{2}$ generations of each cross. Inter and intra row spacing was $45 \mathrm{~cm}$ and $10 \mathrm{~cm}$, respectively. Five plants from each of the $\mathrm{P}_{1}$, $\mathrm{P}_{2}, \mathrm{~F}_{1}, 30$ plants from $\mathrm{F}_{2}$ and 10 plants from each of the $\mathrm{BC}_{1}$ and $\mathrm{BC}_{2}$ generations were randomly selected per replication and observations were recorded on single plant basis for the following characters viz., days to $50 \%$ flowering, days to maturity, number of pods per plant, number of seeds per pod, 100 seed weight and seed yield per plant, on randomly selected plants for all the generations in each replications.

The data were subjected to analysis of variance for Compact Family Block Design following Panse and Sukhatme (1967). The crosses showing significant differences among the entries (progenies) for the character were subjected to generation mean analysis for the estimation of gene effects using six parameter model as suggested by Hayman (1958) and Jinks and Jones (1958). The scaling test as described by Haymen and Mather (1955) was used to check the adequacy of the additive dominance model for different characters in each cross. 


\section{Results and Discussion}

The analysis of variance for the experimental design for all the six characters studied in five crosses of cowpea (Vigna unguiculata (L.) walp) is presented in table 1 . The analysis of variance between families revealed that the mean squares due to crosses were significant for all the characters under study. The Bartlett's test for homogeneity of error variances in five crosses indicated that the error variances were homogeneous for all the characters viz., days to $50 \%$ flowering, days to maturity, number of pods per plant, number of seeds per pod, 100 seed weight and seed yield per plant, as showed by non-significance of chi-square values. The analysis of variance among progenies within each family indicated significant differences among six generation means for all the characters studied in all the five crosses. The crosses that showed significant differences among their respective generations for various characters were considered for studying gene action. The character expression is the manifestation of gene action and its interactions with the environment.

The breeding methodology to be adopted for the genetic improvement of the characters primarily hinges on the type of gene action viz., additive, dominance and epistasis with their relative magnitude. Simple selection procedure would be more rewarding for the character governed by the additive type of gene effects. However, for the characters under the influence of inter-allelic interactions (complimentary or duplicate epistasis), exploitation of heterosis or development of composite and synthetics would precisely be more effective. Production of hybrids as opposed to open pollinated varieties depends largely on the level of dominance or epistasis (dominance $\times$ dominance) or both (Cockerham, 1961). A gain level of dominance and forms of epistasis is influenced by the selection of the parental materials to develop open pollinated varieties. Thus, estimation of additive, dominance and epistasis components of genetic variances are of paramount significance in planning and execution of any plant improvement programme. Empirically estimation of gene action is done on certain assumptions like absence of multiple alleles, lethal genes and linkage, constant viability of all the genotypes and additivity of environmental effects on genotypic value that are rarely fulfilled. A number of genetic models assuming basic requirements have been suggested for the estimation of the gene effects. Hayman (1958), Jinks and Jones (1958), Anderson and Kempthorne (1954) and Hayman and Mather (1955) have developed models for estimating the relative importance of additive and dominance gene effects. Epistasis gene effects were assumed to be negligible. However, significant epistasis gene effects have been reported for quantitative traits in many crops. However, partitioning of total heritable variance in to additive and dominant components ignoring the presence of interallelic gene action does not give a correct picture of the gene action involved.

If the epistatic gene actions are not separated, they tend to inflate dominance variance and lower the additive variance culminating in reduced efficiency of the breeding programme. The six-generations model involving $\mathrm{P}_{1}, \mathrm{P}_{2}, \mathrm{~F}_{1}, \mathrm{~F}_{2}, \mathrm{BC}_{1}$ and $\mathrm{BC}_{2}$ generations in five crosses of cowpea was utilized to ascertain epistasis (additive $x$ additive, additive $\times$ dominance and dominance $x$ dominance) in addition to additive and dominance gene effects for seed yield per plant and its attributing characters. The scaling tests (A, B, C and D) indicated blatant and conspicuous epistasis present in the five crosses for different characters studied. This clearly suggested the failure of a simple genetic model to explain the genetic system controlling the traits in the five crosses studied and need for consideration of epistasis 
in all traits while planning breeding programmes in cowpea.

\section{Days to $50 \%$ flowering}

There were significant differences for this character in all the five crosses. As such they were subjected to scaling test and estimation of gene effects for respective generation. The highly significant values of ' $\mathrm{m}$ ' from the generation mean analysis in all the five crosses showed that the six generation differed from each other with respect to days to $50 \%$ flowering (Table 2). The estimation of gene effects revealed that in cross-I, additive and dominance $\times$ dominance, in cross II, all the six genetics components, in cross III, additive dominance and additive $x$ additive, in cross IV additive, dominance, additive $x$ additive and additive $x$ dominance and in cross $\mathrm{V}$ dominance, additive $\times$ additive and additive $\times$ dominance genetics components were significant. This indicated that in all the crosses, both additive and nonadditive gene effects were important in controlling the trait. The significant opposite sign of dominance and dominance $x$ dominance effects indicated the presence of duplicate epistasis in the inheritance of this trait in cross II. The present findings are akin to the results reported by Ewa Ubi et al., (2001), Ishiyaku et al., (2005), Rashwan (2010), Lal et al., (2013) and Thakare et al., (2016).

\section{Days to maturity}

There were significant differences for this character in all the five crosses. As such they were subjected to scaling test and estimation of gene effects for respective generation. The highly significant values of ' $m$ ' from the generation mean analysis in all the five crosses showed that the six generation differed from each other with respect to days to maturity. The estimation of gene effects revealed that in cross-I, additive, dominance and additive $\times$ additive, in cross II and III, all the six genetics components except additive $\mathrm{x}$ dominance, in cross IV, additive and dominance and in cross $\mathrm{V}$, additive, additive $x$ dominance, and dominance $x$ dominance genetics components were significant. This indicated that in all the crosses, both additive and non-additive gene effects were important in controlling the trait. The significant opposite sign of dominance and dominance $\mathrm{x}$ dominance effects indicated the presence of duplicate epistasis in the inheritance of this trait in cross II and III. These results are in agreement, to the findings of Tefera and Peat (1997), Singh et al., (2006) and Rashwan (2010).

\section{Number of pods per plant}

There were significant differences for this character in all the five crosses. As such they were subjected to scaling test and estimation of gene effects for respective generation. The highly significant values of ' $m$ ' from the generation mean analysis in all the five crosses showed that the six generation differed from each other with respect to number of pods per plant (Table 2).

The estimation of gene effects revealed that in cross I, all the gene effects except dominance were highly significant for number of pods per plant and dominance $\times$ dominance gene effect was greater in magnitude followed by additive $\times$ dominance. In cross II, all the gene effects except additive $\mathrm{x}$ dominance were highly significant with dominance gene effect having higher magnitude. In cross III, dominance and dominance $\times$ dominance gene effects were found significant with dominance $x$ dominance component exhibiting higher magnitude. In cross IV, all the gene effects except dominance $\mathrm{x}$ dominance were highly significant with dominance gene effect having higher magnitude. In cross $\mathrm{V}$, additive and dominance $\times$ dominance genetics components were significant. 
Table.1 Analysis of variance for six generations in five crosses of cowpea for DFF, DM, NPPP, NSPP, HSW and SYPP

\begin{tabular}{|c|c|c|c|c|c|c|c|}
\hline \multirow{2}{*}{ Source } & \multirow[b]{2}{*}{ d. f. } & \multicolumn{6}{|c|}{ Mean sum of square } \\
\hline & & $\begin{array}{c}\text { Days to } 50 \% \\
\text { flowering }\end{array}$ & Days to maturity & $\begin{array}{c}\text { Number of pods } \\
\text { per plant }\end{array}$ & $\begin{array}{l}\text { Number of seeds per } \\
\text { pod }\end{array}$ & 100 seed weight & Seed yield per plan \\
\hline \multicolumn{8}{|c|}{ Analysis of variance between crosses } \\
\hline Replication & 2 & 0.51 & 0.89 & 0.03 & 0.19 & 0.14 & 1.05 \\
\hline Crosses & 4 & $11.49 * *$ & $223.19 * *$ & $12.58^{* *}$ & $6.66^{* *}$ & $1.80 * *$ & $83.28 * *$ \\
\hline Error & 8 & 0.15 & 0.27 & 0.25 & 0.09 & 0.07 & 0.69 \\
\hline \multicolumn{8}{|c|}{ Analysis of variance between generations within cross } \\
\hline \multicolumn{8}{|c|}{ Cross - I (Pant Lobia -1 x BRDCP-11) } \\
\hline Replication & 2 & 3.54 & 0.08 & 0.74 & 0.16 & 0.14 & 2.17 \\
\hline Generation & 5 & $11.64 * *$ & $40.40 * *$ & $18.14^{* *}$ & $5.57 * *$ & $6.24 * *$ & $32.57 * *$ \\
\hline Error & 10 & 0.90 & 0.87 & 1.07 & 0.41 & 1.03 & 5.08 \\
\hline \multicolumn{8}{|c|}{ Cross - II (Pant Lobia-2 x GC-3) } \\
\hline Generation & 5 & $28.84 * *$ & $230.89 * *$ & $25.69 * *$ & $5.66^{*}$ & $6.37 * *$ & $44.07 *$ \\
\hline Error & 10 & 1.38 & 2.41 & 2.81 & 1.23 & 0.83 & 9.30 \\
\hline \multicolumn{8}{|c|}{ Cross - III (Waghi Local x W-203-1) } \\
\hline Replication & 2 & 1.76 & 3.88 & 2.19 & 0.47 & 1.39 & 2.45 \\
\hline Generation & 5 & $19.54 * *$ & $24.01 * *$ & $30.94 * *$ & $4.70^{* *}$ & $4.52 * *$ & $210.35 * *$ \\
\hline Error & 10 & 1.57 & 1.99 & 1.48 & 0.40 & 0.56 & 7.22 \\
\hline \multicolumn{8}{|c|}{ Cross - IV (KM-5 x GC-3) } \\
\hline Replication & 2 & 0.08 & 2.78 & 1.69 & 0.21 & 0.09 & 0.99 \\
\hline Generation & 5 & $34.05 * *$ & $53.95^{* *}$ & $17.41^{* *}$ & $7.52 * *$ & $3.67 * *$ & $44.53 *$ \\
\hline Error & 10 & 0.98 & 2.23 & 1.67 & 0.53 & 0.45 & 5.97 \\
\hline \multicolumn{8}{|c|}{ Cross - V (GC-3 x CDP-107) } \\
\hline Replication & 2 & 0.73 & 2.33 & 1.54 & 2.14 & 0.79 & 2.15 \\
\hline Generation & 5 & $20.71 * *$ & $33.90 * *$ & $14.46^{* * *}$ & $20.13 * *$ & $1.58^{*}$ & $19.74^{*}$ \\
\hline
\end{tabular}

$*$, ** Significant at 5 per cent and 1 per cent levels of significance, respectively 
Table.2 The result of scaling tests and estimates of gene effects for DFF, DM, NPPP, NSPP, HSW and SYPP in five crosses of cowpea

\begin{tabular}{|c|c|c|c|c|c|c|c|c|c|c|c|}
\hline Cross & $\mathbf{A}$ & B & $\mathbf{C}$ & D & m & d & $\mathbf{h}$ & $\mathbf{i}$ & $\mathbf{j}$ & 1 & Gene Action \\
\hline \multicolumn{12}{|c|}{ Days to $50 \%$ flowering } \\
\hline I & $-3.46^{*}$ & $-7.95 * *$ & $-7.08 *$ & 2.17 & $43.45 * *$ & $3.33 * *$ & -1.8 & -4.33 & 2.24 & $15.74 * *$ & - \\
\hline II & 2.33 & $-9.52 * *$ & $7.61^{*}$ & $7.4 * *$ & $48.63 * *$ & $7.87 * *$ & $-14.42 * *$ & $-14.80 * *$ & $5.92 * *$ & $21.99 * *$ & Duplicate \\
\hline III & $5.55 * *$ & 2.21 & $20.55 * *$ & $6.40 * *$ & $44.89 * *$ & $2.53 *$ & $-17.27 * *$ & $-12.79 * *$ & 1.66 & 5.03 & - \\
\hline IV & 0.51 & $-10.16^{* *}$ & $-21.54 * *$ & $-5.95^{* *}$ & $42.91 * *$ & $6.63 * *$ & $16.68^{* *}$ & $11.89 * *$ & $5.33 * *$ & -2.24 & - \\
\hline $\mathbf{V}$ & $-5.15 * *$ & 0.25 & $-15.64 * *$ & $-5.37 * *$ & $41.91 * *$ & -1.07 & $16.46 * *$ & $10.75 * *$ & $-2.70 * *$ & -5.85 & - \\
\hline \multicolumn{12}{|c|}{ Days to maturity } \\
\hline I & $-4.70 * *$ & $-6.23 * *$ & $-19.23 * *$ & $-4.15^{*}$ & $87.39 * *$ & $4.13 * *$ & $14.36 * *$ & $8.30 *$ & 0.76 & 2.63 & - \\
\hline II & -0.21 & 0.72 & $-17.51 * *$ & $-9.01 * *$ & $84.05 * *$ & $11.23 * *$ & $25.19 * *$ & $18.01 * *$ & -0.46 & $-18.52 * *$ & Duplicate \\
\hline III & 2.17 & 0.32 & $22.22 * *$ & $9.87 * *$ & $75.75 * *$ & $2.77 *$ & $-23.43 * *$ & $-19.73 * *$ & 0.92 & $17.24 * *$ & Duplicate \\
\hline IV & $4.32 *$ & $4.52 *$ & $8.29 *$ & -0.28 & $82.64 * *$ & $3.37 *$ & $8.49 *$ & 0.56 & -0.10 & -9.40 & - \\
\hline $\mathbf{V}$ & $-16.53 * *$ & -2.20 & $-17.93 * *$ & 0.40 & $69.47 * *$ & $-5.73 * *$ & 3.70 & -0.80 & $-7.16^{* *}$ & $19.53 * *$ & - \\
\hline \multicolumn{12}{|c|}{ Number of pods per plant } \\
\hline I & -0.27 & $-11.33 * *$ & -3.20 & $4.20 * *$ & $20.85 * *$ & $3.9 * *$ & -4.37 & $-8.4 * *$ & $5.53 * *$ & $20.00 * *$ & - \\
\hline II & -1.76 & 2.37 & $-16.93 * *$ & $-8.76^{* *}$ & $17.33 * *$ & $-3.7 * *$ & $22.66 * *$ & $17.53 * *$ & -2.06 & $-18.13 * *$ & Duplicate \\
\hline III & $-8.33 * *$ & $-8.67 * *$ & $-19.6^{* *}$ & -1.30 & $22.20 * *$ & 2.10 & $8.53 *$ & 2.60 & 0.16 & $14.40^{*}$ & Complementary \\
\hline IV & 1.00 & $-3.97 * *$ & $-13.88 * *$ & $-5.46^{* *}$ & $20.59 * *$ & $3.70 * *$ & $15.33 * *$ & $10.92 * *$ & $2.48 *$ & -7.94 & - \\
\hline $\mathbf{V}$ & -1.90 & $-4.47 * *$ & 0.03 & 3.20 & $20.33 * *$ & $3.33 * *$ & -2.92 & -6.4 & 1.28 & $12.76^{*}$ & - \\
\hline \multicolumn{12}{|c|}{ Number of seeds per pod } \\
\hline I & $-2.47 *$ & $-3.00 * *$ & $-5.33 * *$ & 0.07 & $9.08 * *$ & $1.83 * *$ & -0.03 & -0.13 & 0.26 & 5.6 & - \\
\hline II & -0.86 & 1.34 & -1.94 & -1.21 & $11.77 * *$ & $-2.74 *$ & 2.44 & 2.43 & -1.09 & -2.91 & - \\
\hline III & $-2.47 *$ & -2.07 & $5.13 *$ & $4.83 * *$ & $14.07 * *$ & 0.77 & $-8.03 * *$ & $-9.67 * *$ & $-0 . .20$ & $14.20 * *$ & Duplicate \\
\hline IV & -0.47 & -0.53 & -2.07 & -0.53 & $10.88 * *$ & $-2.17 * *$ & 0.53 & 1.07 & 0.03 & -0.06 & - \\
\hline $\mathbf{V}$ & $-5.58 * *$ & 2.02 & $-16.14 * *$ & $-6.29 * *$ & $11.11 * *$ & $-2.43 * *$ & $17.86 * *$ & $12.58 * *$ & $-3.80^{* *}$ & $-9.02 *$ & Duplicate \\
\hline \multicolumn{12}{|c|}{$100-$ seed weight $(\mathrm{gm})$} \\
\hline I & $-4.38 *$ & -2.13 & 1.94 & $4.22 * *$ & $11.85 * *$ & 0.61 & $-8.07 *$ & $-8.45 * *$ & -1.12 & $14.95 * *$ & Duplicate \\
\hline II & -1.01 & $-4.31 * *$ & $5.15^{*}$ & $5.23 * *$ & $14.05 * *$ & $2.11 *$ & $-8.21 * *$ & $-10.47 * *$ & 1.64 & $15.78 * *$ & Duplicate \\
\hline III & $-2.53 * *$ & $-1.87 *$ & -0.07 & $2.17 *$ & $13.00 * *$ & 0.37 & -1.43 & $-4.33 *$ & -0.33 & $8.73 * *$ & - \\
\hline IV & 0.21 & 1.06 & $-3.29 *$ & $-2.28 *$ & $11.26^{* *}$ & -0.80 & $7.14 * *$ & $4.56^{*}$ & -0.42 & $-5.83 *$ & Duplicate \\
\hline $\mathbf{V}$ & 0.10 & -0.21 & $6.46 * *$ & $3.29 * *$ & $12.09 * *$ & 0.41 & $-7.33 * *$ & $-6.57 * *$ & 0.15 & 6.69 & - \\
\hline \multicolumn{12}{|c|}{ Seed yield per plant $($ gm) } \\
\hline I & -1.72 & -0.24 & $-10.25 * *$ & $-4.15 * *$ & $20.81 * *$ & $3.45^{* *}$ & $12.14 * *$ & $8.29 * *$ & -0.74 & -6.33 & - \\
\hline II & $6.70 *$ & $-11.12 * *$ & $-14.91 * *$ & -5.25 & $26.32 * *$ & $6.10 * *$ & $17.58 * *$ & 10.49 & $8.91 * *$ & -6.07 & - \\
\hline III & $-17.94 * *$ & $-18.13 * *$ & -7.26 & $14.40 * *$ & $39.82 * *$ & $7.47 * *$ & $-13.58 *$ & $-28.8 * *$ & 0.09 & $64.86^{* *}$ & Duplicate \\
\hline IV & -3.45 & $-11.84 * *$ & $-9.22 *$ & 3.03 & $27.63 * *$ & 0.79 & 2.00 & -6.06 & $4.19 * *$ & $21.34 * *$ & - \\
\hline V & -0.4 & -3.92 & $-13.70^{*}$ & -4.69 & $25.55^{* *}$ & 3.97 & $13.10^{*}$ & 9.37 & 1.76 & -5.04 & - \\
\hline
\end{tabular}

Cross I (Pant Lobia -1 x BRDCP-11), Cross II (Pant Lobia-2 x GC-3), Cross III (Waghi Local x W-203-1), Cross IV (KM-5 x GC-3), Cross V (GC-3 x CDP-

107) 
The significant same sign of dominance and dominance $\mathrm{x}$ dominance effects indicated the presence of complimentary epistasis in the inheritance of this trait in cross III and the significant opposite sign of dominance and dominance $\mathrm{x}$ dominance effects indicated the presence of duplicate epistasis in the inheritance of this trait in cross II These results are in concurrence to the findings of Rashwan (2010), Lal et al., (2013) and Thakare et al., (2016) for number of pods per plant. This attribute being an important yield attributing character in cowpea, cyclic method of breeding (recurrent selection) could profitably be utilized to take advantage of both additive and non-additive type of gene actions for the improvement of this trait.

\section{Number of seeds per pod}

For number of seeds per pod there were significant differences in all the five crosses. As such they were subjected to scaling test and estimation of gene effects for respective generation. The highly significant values of ' $\mathrm{m}$ ' from the generation mean analysis in all the five crosses showed that the six generation differed from each other with respect to this trait (Table 2). The estimates of gene effects showed that in cross I, additive gene effects were highly significant for number of seed per pod. In cross III, dominance, additive $\times$ dominance and dominance $\times$ dominance effects were highly significant, whereas in cross $\mathrm{V}$, all the six genetics components were highly significant. All the four scaling test viz., A, B, C and D were found nonsignificant in cross II and IV indicating adequacy of the additive-dominance model for explaining the gene effects in cross II and IV for this trait. According to Jinks and Jonse three parameter model additive [d] gene effects play important role for controlling this trait in particular these two crosses. The significant opposite signs of dominance and dominance $\mathrm{x}$ dominance effects indicated the presence of duplicate epistasis in the inheritance of this trait in crosses III and V. The present findings are in conformity to the results of Drabo et al., (1985), Singh et al., (2006), Lal et al., (2013) and Thakare et al., (2016) who reported that additive, dominance and epistatic effect were most important for inheritance of seeds per pod in cowpea. The involvement of both additive and non-additive gene effects in the genetic control of this trait suggested that homozygous elite recombinants could be developed following inter-crossing of desirable segregants.

\section{0 seed weight $(\mathrm{g})$}

There were significant differences for this character in all the five crosses. As such they were subjected to scaling test and estimation of gene effects for respective generation. The highly significant values of ' $\mathrm{m}$ ' from the generation mean analysis in all the five crosses showed that the six generation differed from each other with respect to 100 seed weight (Table 2). The estimates on gene effect for test weight revealed that additive $x$ additive and dominance $\times$ dominance gene effect were highly significant whereas dominance gene effect was significant in cross I. In cross II, dominance, additive $\times$ additive and dominance $\times$ dominance gene effects were highly significant and additive effect was significant. In cross III, dominance $\times$ dominance gene effects was highly significant whereas additive $\times$ dominance gene effect was significant. In cross IV, dominance, additive $\times$ additive and dominance $x$ dominance gene effect were highly significant whereas in cross $\mathrm{V}$, dominance and additive $\times$ additive gene effect were highly significant. The significant opposite signs of dominance and dominance $\mathrm{x}$ dominance effects indicated the presence of duplicate epistasis in the inheritance of this trait in cross I, III and IV. Lopes et al., (2003) reported that additive effect was the more 
important genetic parameter for determination of this character. The involvement of additive and non-additive gene effects suggested that homozygous elite recombinants could be developed following inter-mating of desirable segregants. Overall, conspicuous duplicate epistasis was evident in all the five crosses for predominant characters as revealed by difference in signs of (d) and (dd) in crosses. These findings illustrated that importance of duplicate epistasis in genetic consideration of different characters studied in cowpea. These results are in agreement with those reported by Rashwan (2002), Abd-Elkader (2006) and Singh et al., (2006), Thakare et al., (2016) and Zaher (2016). However, these results are in contrast to the findings of Sherif and Damarany (1992) and El-Ameen (2008), who have reported both complementary and duplicate type of non-allelic gene interaction in their studies. From the present investigation, it can be concluded that appreciable amount of epistasis present in different characters of five crosses under the study. Breeding methods involving high volume crossing like biparental, recurrent and diallel selective mating design that take care of both additive and non-additive gene action seemed more promising for the improvement of various characters studied.

\section{Seed yield per plant}

There were significant differences for this character in all the five crosses. As such they were subjected to scaling test and estimation of gene effects for respective generation. The highly significant values of ' $\mathrm{m}$ ' from the generation mean analysis in all the five crosses showed that the six generation differed from each other with respect to seed yield per plant (Table 2). The estimates of gene effects for seed yield per plant revealed that in cross I, additive, dominance and additive $x$ additive gene effects were highly significant with dominance component higher in magnitude, next in order was additive $x$ additive effect. In cross II, additive, dominance and additive $\times$ dominance gene effect were highly significant. In cross III, additive, dominance, additive $\times$ additive and dominance $\times$ dominance gene effects were highly significant, where the magnitude of dominance $\times$ dominance gene effect was highest followed by additive $\times$ additive effect. In cross IV, additive $\times$ dominance and dominance $x$ dominance gene effects were highly significant, where in cross V dominance gene effects were significant. The significant opposite signs of dominance and dominance $\mathrm{x}$ dominance effects indicated the presence of duplicate epistasis in the inheritance of this trait in cross III. The involvement of additive gene effects along with predominant non-additive gene effects suggested that recurrent selection could profitably be utilized to take advantage of both additive and non-additive type of gene actions for the improvement of seed yield per plant. The present findings are in agreement to the results obtained by Pathmanathan et al., (1997), Tefera and Peat (1997), Singh et al., (2006), Rashwan (2010), Adeyanju et al., (2012), Lal et al., (2013), jog et al., (2016), Thakare et al., (2016) and Zaher (2016).

In conclusion, the system of breeding that can be employed for exploiting any character depends upon the type of gene action involved for its expression. The type and magnitude of gene effects differed for different characters in the same cross and for the same character in different crosses, which necessitates specific handling of individual cross in segregating generations. In the present investigation, non-allelic interaction played pertinent role in determination of various characters. Thus, breeding methods involving high volume crossing like biparental, recurrent and diallel selective mating design that take care of both additive and non-additive gene action seemed more 
promising for the improvement of various characters studied. The characters controlled by additive gene effect can be improved most appropriate method of breeding would be pedigree method of selection.

\section{References}

Abd-Elkader, N. A. M. 2006. Genetic analysis of some economic traits in cowpea [Vigna unguiculata (L.) Walp]. M.Sc. Thesis, Faculty of Agriculture, Assiut University, Egypt.

Adeyanju, A. O., Ishiyaku, M. F., Echekwu, C. A. and Olarewaju, J. D. 2012. Generation mean analysis of dual purpose traits in cowpea (Vigna unguiculata [L.] Walp). African Journal of Biotechnology, 11(46): 10473-10483.

Anderson, V. L. and Kempthorne, O. 1954. A model for study of quantitative. Genetics, 9: 881-898.

Cockerham, C. C. 1961. Implication of genetic varaiances in hybrid breeding programme. Crop Science, 1: 47-52

Drabo, I., Ladeinde, T. A. O., Radden, R. and Smithson. J. B. 1985.Inheritance of seed size and number per pod in cowpeas. Field Crop Research, 11: 335-344.

El-Ameen, T. M. 2008. Genetic components of some economic traits in cowpea Vigna ungiculata. Journal of Agricultural Science, Mansoura Univ., 33: 135-149.

Ewa Ubi, B., Mignouna, H. and Obigbesan, G. 2001. Segregation for seed weight, pod length and days to flowering following a cowpea cross. African Crop Science Journal, 9(3): 463-470.

Hayman, B. I. 1958. The separation of epistatic from additive and dominance variation in generation means. Heredity, 12: 371- 390.

Hayman, B. I. and Mather, K. 1955. The description of genetic interaction in continuous variation. Biometrics, 11: 69-82.

Ishiyaku, M. F., Singh, B. B. and Craufurd, P. Q. 2005. Inheritance of time to flowering in cowpea. [Vigna unguiculata (L.) Walp.]. Euphytica, 142: 242-291.

Jinks, J. L. and Jones, R. M. 1958. Estimation of the components of heterosis. Genetics. 43(2): 223-234.

Jog, K. H., Kachhadia, V. H., Vachhani, J. H. and Lalwani, H. H. 2016. Generation mean analysis and inbreeding depression in pearl millet [Pennisetum glaucum (L.) R. Br.]. Electronic Journal of Plant Breeding, 7 (3): 469481.

Lal, J. J., Danghi, K. S., Kumar, S. and Suresh, J. 2013. Scaling and joint scaling test for quantitative traits of generation mean analysisin sesame (Sesamum indicum L.). J. Oilseeds Res., 30 (1): $1-5$.

Lopes, F. C. C, Gomes, R. L. F and Filho, F. R. F. 2003. Genetic control of cowpea seed sizes. Scientia Agricola, 60(2): doi: 10 .

Panse, V.G. and Sukhatme, P.V. 1967. Statistical Methods for Agricultural Workers. Indian Council of Agricultural Research, New Delhi.

Pathmanathan, U., Ariyanayagam, R. P. and Haque, S. Q. 1997. Genetic analysis of yield and its component in vegetable cowpea (Vigna unguiculata [L.] Walp.). Euphytica, 96(2): 207-213.

Rashwan, A. M. A. 2002. Genetic studies on some Agro-economic characteristics in cowpea [Vigna unguiculata (L.) Walp.] Ph.D. Thesis, Faculty of Agriculture, Assuit University, Egypt.

Rashwan, A. M. A. 2010. Estimation of some genetic parameters using six populations of two cowpea hybrids. Asian Journal of Crop Science, 2: 261267. 
Schultze, M. and Kondorosi, A. 1998. Regulation of symbiotic root nodule development. Annual Review of Genetics, 32:33-57.

Sherif, T. H. I. and Damarany, A. M. 1992. Influence of environment on the manifestation of complementary and duplicate gene interaction for quantitative gene interaction for quantitative characters in cowpea (Vigna unguiculata L.) Walp. Assuit Journal of Agricultural Science, 23: 81103.

Singh, I., Gill, M. S. and Bains, T. S. 2006. Generation mean analysis for yield attributing traits in mung bean [Vigna radiata (L.) Wilczek]. Indian J. Genet., 66 (1): 47-48.

Stanton, W. R. 1966. Grain legumes in Africa. Food and agricultural organization of the United Nations, Rome, Italy, pp. 210-213.

Tefera, H. and Peat, W. E. 1997. Genetics of grain yield and other agronomic characters in t'ef. (Eragrostis tef Zucc Trotter). I. Generation means and variances analysis. Euphytica, 96: 185191.

Thakare, D. S., Bhailume, M. S., Rokade, R. C., Pulate, S. C. and V. P. Chimote 2016. Genetic analysis of various yield components in cowpea. [Vigna unguiculata (L.) Walp.]. International Journal of Tropical Agriculture 34 (6): 1905-1913.

Yadav, K. S., Yadav, H. S. and Dixit, H. 2010. Heterosis and inbreeding depression in cowpea, International Journal of Agricultural Science, 6(2): 537-540.

Yamada, N. 1974. Biological nitrogen fixation - limit less resources supporting agriculture. Nettai Noken Shubo, 25: 20-28.

Zaher, I. N. A. E. 2016. Inheritance of seed yield and some yield components of faba bean using six populations. Assiut J. Agric. Sci., 47 (4): 32-40.

\section{How to cite this article:}

Gupta, R.P., S.R. Patel, K.G. Modha and Wadekar, P.B. 2017. Generation Mean Analysis for Yield and Yield Components in Cowpea [Vigna unguiculata (L.) Walp.]. Int.J.Curr.Microbiol.App.Sci. 6(7): 2231-2240. doi: https://doi.org/10.20546/ijcmas.2017.607.262 